\title{
SUSCEPTIBILITY OF MYCOBACTERIUM LEPRAE TO THE BACTERICIDAL ACTIVITY OF MOUSE PERITONEAL MACROPHAGES AND TO HYDROGEN PEROXIDE
}

\author{
A. K. Sharp, M. J. Colston* and D. K. BanerJeE \\ Department of Medical Microbiology, St George's Hospital Medical School, London
} SW17 ORE

\begin{abstract}
SUMMARY. Macrophages from athymic nude mice were infected in vitro with Mycobacterium leprae to study the intracellular fate of this organism. Using the proportional bactericidal test, we have shown that the viability of $M$. leprae declines rapidly within these macrophages, although results of clearance experiments demonstrate that live and killed organisms are cleared at comparable rates. We have also shown that $M$. leprae is susceptible to the bactericidal effects of hydrogen peroxide and we suggest that hydrogen peroxide generated by macrophages is responsible for the killing of intracellular $M$. leprae.
\end{abstract}

\section{INTRODUCTION}

Although one of the primary sites of multiplication of Mycobacterium leprae in susceptible hosts is within macrophages, attempts to grow the organism in cultures of macrophages from normal mice (Chang and Neikirk, 1965; Yamagami and Chang, 1977), athymic mice and armadillos (Sharp and Banerjee, 1984) and man (Samuel et al., 1973) have all failed. The reasons for this failure are unknown but might be a lack of essential growth requirements or susceptibility to intracellular killing mechanisms in macrophages maintained in vitro.

Alternatively, slow bacillary multiplication may occur but be balanced by removal of dead organisms. We have recently published the results of attempts to culture $M$. leprae in macrophages derived from congenitally athymic (nude) mice (Sharp and Banerjee, 1984), in which we were unable to demonstrate significant bacillary increases. This report describes studies in which the intracellular fate of $M$. leprae has been examined in terms of elimination of killed organisms, and intracellular killing of bacteria. The bactericidal effect of hydrogen peroxide on $M$. leprae in vitro has also been investigated. Hydrogen peroxide is thought to be a major component of the antibacterial activity of the macrophage (Walker and Lowrie, 1981; Haidaris and Bonventre, 1982) and may be of particular relevance in the intracellular killing of $M$.

Received 2 Apr. 1984; accepted 29 Jun. 1984.

*Present address: Laboratory for Leprosy and Mycobacterial Research, National Institute for Medical Research, Mill Hill, London NW7.

Correspondence should be sent to Dr D.K.Banerjee. 
leprae given the inability to detect catalase activity associated with this organism (Wheeler and Gregory, 1980; Katoch, Wayne and Diaz, 1982).

\section{MATERIALS AND METHODS}

Macrophage cultures. Macrophages were harvested from adult athymic nude mice bred in St George's Hospital Medical School Animal Unit, and maintained in isolators. Macrophages were washed from the peritoneal cavity by injecting $5 \mathrm{ml}$ of medium NCTC 109 (Difco) supplemented with preservative-free heparin $10 \mathrm{IU} / \mathrm{ml}$ and ampicillin $100 \mathrm{mg} / \mathrm{L}$. After gentle agitation the macrophage suspension was withdrawn through a wide gauge needle $(21 \mathrm{G})$ into a plastic syringe. At least $50 \%$ of the cells were judged to be macrophages after Leishman staining. Macrophages were dispensed into plastic flat-based tissue culture tubes (Nunc), (1-2) $\times 10^{6} /$ tube, and incubated overnight at $35^{\circ} \mathrm{C}$ in $\mathrm{CO}_{2} 5 \%$ in air to allow cells to adhere. The old medium was replaced with $1 \mathrm{ml}$ of culture medium NCTC 109 supplemented with horse serum (Gibco) $40 \%$, beef embryo extract (Difco) $2 \%$ and ampicillin $100 \mathrm{mg} / \mathrm{L}$ as described by Chang (1964).

Bone-marrow macrophages were harvested from the femora of nude mice. The bones were dissected out and the heads of the bone shafts were cut off. With a 25 gauge needle and $2 \mathrm{ml}$ of the heparinised medium described above, the bone marrow was washed from the cavity. Cell aggregates were broken up by repeated aspiration and the suspension was dispensed at 1 $\mathrm{ml} /$ culture tube. After a $24 \mathrm{~h}$ period for adherence, the cultures were washed to remove non-adherent cells and then maintained at $37^{\circ} \mathrm{C}$ in $\mathrm{CO}_{2} 5 \%$ in air. The medium was changed every 14 days.

Bacterial suspensions and cultures. $M$. leprae suspensions were derived from two sources. Human biopsies were taken from lepromatous patients in Africa or India as part of a World Health Organization study, transported on ice and used to infect cultures approximately 3 days after excision of the biopsy. Footpads of nude mice in which $M$. leprae had been passaged were also used. Tissue was homogenised in glass grinders in saline containing albumin $0.1 \%$, and bacilli were counted by the method of Holmes and Hilson (1972) with a PTFE-coated microscope slide (C. A. Hendley (Essex) Ltd). The number of acid fast bacilli/circle diameter was counted and used in conjunction with the calibration of the microscope field to calculate the number of bacilli/ml of suspension. $M$. leprae were killed either by heating at $60^{\circ} \mathrm{C}$ for $60 \mathrm{~min}$ in a water bath, or by exposure to 2.5 Megarads of $\gamma$-irradiation from a ${ }^{60} \mathrm{Co}$ source.

Clinical isolates of $M$. tuberculosis were grown in Dubos liquid medium. Catalase-positive and catalase-negative strains were selected. Staphylococus aureus NCTC 6971 and two clinical isolates of Streptococcus pyogenes were grown in Brain-Heart Infusion Broth (Oxoid).

Infection and maintenance of macrophage cultures and recovery of intracellular bacilli. Macrophage cultures were infected by replacing old medium with $1 \mathrm{ml}$ of culture medium containing $10^{6} \mathrm{M}$. leprae. After an overnight phagocytic period, cultures were washed three times with phosphate buffered saline (PBS) and then maintained for as long as possible. At each medium change (every 14 days), old medium was pooled and stored so that any bacilli lost from the culture could be included in the final count as described elsewhere (Sharp and Banerjee, 1984). Immediately after the phagocytic period (for a baseline count) and at various time intervals, $M$. leprae-infected cultures were exposed to two 30 -s bursts of mild ultrasonication at $800 \mathrm{KHz}$ (Luziesa, Paris, France). This breaks the host-cell membrane without damaging bacilli (Brown and Brown, 1982). Total counts were performed on these M. leprae suspensions, and in some experiments viability was assessed by the proportional bactericidal test (described below).

Exposure of bacterial suspensions to hydrogen peroxide. Organisms were suspended in PBS or PBS containing $\mathrm{H}_{2} \mathrm{O}_{2} 0.08 \%$ to give a count of about $10^{6}$ bacteria $/ \mathrm{ml}$. The concentration was chosen on the basis of a previous study on the susceptibility of $M$. tuberculosis to $\mathrm{H}_{2} \mathrm{O}_{2}$ (Jackett, Aber and Lowrie, 1978). Suspensions were incubated at $37^{\circ} \mathrm{C}$, and at appropriate intervals samples of these suspensions were removed and viable counts were made.

Estimations of bacterial viability. Viable counts of $M$. tuberculosis, Staph. aureus and Str. pyogenes were estimated by the method of Miles and Misra, as described by Collins and Lyne (1970). The viability of $M$. leprae was estimated by the proportional bactericidal test (Hilson and Banerjee, 1974; Colston, Hilson and Banerjee, 1978). Briefly, M. leprae suspensions obtained 
from sonicates of macrophage cultures, or after hydrogen peroxide treatment, and serial tenfold dilutions thereof, were injected into the footpads of groups of mice. Twelve months later, footpads were harvested and each group was scored for the number of footpads infected (i.e., showing growth of $M$. leprae) per number of footpads inoculated. From these figures, the most probable number of viable organisms was calculated with the equation derived by Halvorson and Ziegler (1933), shown below (for the use of three dilutions of the infecting inoculum):

$$
\frac{\mathrm{a}_{1} \mathrm{p}_{1}}{1-\mathrm{e}^{\mathrm{a}} 1^{\mathrm{x}}}+\frac{\mathrm{a}_{2} \mathrm{p}_{2}}{1-\mathrm{e}^{-\mathrm{a}} 2^{\mathrm{x}}}+\frac{\mathrm{a}_{3} \mathrm{p}_{3}}{1-\mathrm{e}^{-\mathrm{a}} 3^{\mathrm{x}}}=\mathrm{a}_{1} \mathrm{n}_{1}+\mathrm{a}_{2} \mathrm{n}_{2}+\mathrm{a}_{3} \mathrm{n}_{3}
$$

where $\mathrm{p}=$ number of footpads infected, $\mathrm{n}=$ number of footpads inoculated, $\mathrm{a}=$ dilution of original inoculum per footpad, and $\mathrm{x}=$ the most probable number of viable organisms in the original inoculum (i.e., per $10^{4} \mathrm{M}$. leprae). The equation was solved for $\mathrm{x}$ by computer, substituting various values for $\mathrm{x}$.

\section{RESULTS}

\section{Clearance of live and killed $M$. leprae by macrophages in vitro}

In our previous report (Sharp and Banerjee, 1984) we were unable to demonstrate any significant changes in the numbers of $M$. leprae harvested from athymic (nude) mouse macrophages even after 200 days in culture. A possible explanation for this is that whilst a low level of multiplication occurs, dead organisms are slowly disrupted and cleared by the cell. This point was investigated by inoculating macrophage cultures with killed $M$. leprae and comparing the clearance of these organisms with that of the corresponding 'live' suspension used to infect similar cultures. (The viability of an $M$. leprae suspension is generally considered to be low $-<20 \%$ - and so a large number of dead organisms are also present in 'live' suspensions.) This comparison was made after lysing macrophages and counting the released $M$. leprae stained by the Ziehl-Neelsen method. In one experiment (table I, experiment 2) inoculation of peritoneal macrophages with live or heat killed $M$. leprae showed that the killed organisms were phagocytosed considerably less avidly than the live organisms. However, over a period of 50 days, no significant difference was observed in the rate of clearance of live and killed $M$. leprae. In two other experiments, one in peritoneal macrophages (table I,

TABLE I

Clearance of live and killed $M$. leprae by macrophages in vitro

\begin{tabular}{|c|c|c|c|c|c|c|}
\hline & $\begin{array}{l}\text { Macrophage } \\
\text { source }\end{array}$ & $\begin{array}{l}\text { Inoculum source } \\
\left(M \text {. leprae } 10^{6} / \mathrm{ml}\right)\end{array}$ & $\begin{array}{l}\text { Live } \\
\text { or } \\
\text { killed }\end{array}$ & $\begin{array}{c}\text { Initial count } \\
(M . \text { leprae } / \mathrm{ml})^{*}\end{array}$ & $\begin{array}{c}\text { Final count } \\
\left(M . \text { leprae } / \mathrm{ml}^{*}\right)\end{array}$ & $\begin{array}{c}\text { Duration } \\
\text { of culture } \\
\text { (days) }\end{array}$ \\
\hline Expt 1 & $\begin{array}{l}\text { Nude mouse, } \\
\text { peritoneal }\end{array}$ & $\operatorname{Man}(1 \cdot 0)$ & $\begin{array}{c}\text { Live } \\
\text { Heat killed }\end{array}$ & $\begin{array}{l}1.6 \times 10^{6} \\
\left( \pm 0.3 \times 10^{5}\right) \\
2.5 \times 10^{5} \\
\left(+0.1 \times 10^{5}\right)\end{array}$ & $\begin{array}{l}1.4 \times 10^{5} \\
\left( \pm 0.2 \times 10^{5}\right) \\
7.9 \times 10^{4} \\
\left(+2.6 \times 10^{4}\right)\end{array}$ & 50 \\
\hline Expt 2 & $\begin{array}{l}\text { Nude mouse, } \\
\text { peritoneal }\end{array}$ & $\operatorname{Man}(1 \cdot 0)$ & \begin{tabular}{l}
\multicolumn{1}{c}{ Live } \\
Killed by \\
$\gamma$-irradiation
\end{tabular} & $\begin{array}{l}1.2 \times 10^{5} \\
\left( \pm 0.7 \times 10^{5}\right) \\
1.9 \times 10^{5} \\
\left( \pm 0.7 \times 10^{5}\right)\end{array}$ & $\begin{array}{l}1.5 \times 10^{5} \\
\left( \pm 0.3 \times 10^{5}\right) \\
2.2 \times 10^{5} \\
\left( \pm 0.3 \times 10^{5}\right)\end{array}$ & 104 \\
\hline Expt 3 & $\begin{array}{l}\text { Nude mouse, } \\
\text { bone marrow }\end{array}$ & $\operatorname{Man}(1 \cdot 0)$ & $\begin{array}{l}\text { Live } \\
\text { Killed by } \\
\gamma \text {-irradiation }\end{array}$ & $\begin{array}{l}2.6 \times 10^{5} \\
\left( \pm 0.4 \times 10^{5}\right) \\
1.5 \times 10^{5} \\
\left( \pm 0.3 \times 10^{5}\right)\end{array}$ & $\begin{array}{l}2.0 \times 10^{5} \\
( \pm 0) \\
1.7 \times 10^{5} \\
\left( \pm 0.7 \times 10^{5}\right)\end{array}$ & 104 \\
\hline
\end{tabular}

*Each figure represents the mean of three cultures \pm SD. 
experiment 2) and one in bone-marrow (table I, experiment 3) no difference was seen in either the rates of phagocytosis or the rates of clearance between live $M$. leprae or $M$. leprae killed by $\gamma$-irradiation, after 104 days in culture.

\section{Survival of $M$. leprae in macrophage cultures}

The viability of $M$. leprae after various periods in macrophage culture was assessed in two experiments by the proportional bactericidal test. Results are shown in table II. In both cases, $M$. leprae suspensions were found to have a rather low initial viability (1.41 viable organisms/ $10^{4}$ bacilli in experiment 1 and 2.76 viable organisms $/ 10^{4}$ bacilli in experiment 2). A gradual decline in numbers of viable $M$. leprae during in-vitro cultivation in macrophages was demonstrated, and at the end of the observation period (after 76 days and 90 days) no viable organisms were detected.

\section{Viability of $M$. leprae after exposure to hydrogen peroxide}

Pilot experiments in which catalase-negative and catalase-positive strains of $M$. tuberculosis, Staph. aureus and Str. pyogenes were exposed to $\mathrm{H}_{2} \mathrm{O}_{2} 0.08 \%$ showed that catalase-negative strains were far less able to survive this treatment than catalase-positive strains. The results of a typical experiment with $M$. tuberculosis are shown in table III. It can be seen that with catalase-negative and catalase-positive strains, incubated in PBS only, there was very little change in viability in the $4 \cdot 5-\mathrm{h}$ duration of the experiment. After exposure to $\mathrm{H}_{2} \mathrm{O}_{2}$ for this period there was only a slight loss of viability in catalase-positive strains. The catalase-negative strains, on the other hand, showed a high level of susceptibility to $\mathrm{H}_{2} \mathrm{O}_{2}$; no viable organisms were recovered after $45 \mathrm{~min}$ of $\mathrm{H}_{2} \mathrm{O}_{2}$ treatment in one strain, and after 90 min of $\mathrm{H}_{2} \mathrm{O}_{2}$ treatment in the other strain. Similar differences were observed in the survival of Str. pyogenes (catalase-negative) and Staph. aureus (catalase-positive) in the presence of $\mathrm{H}_{2} \mathrm{O}_{2} \quad 0.08 \%$ (table IV).

The effect of hydrogen peroxide upon the survival of $M$. leprae was measured by the proportional bactericidal test to assess viability. Results are shown in table V. It can be

TABLE II

Change of viability of $M$. leprae after in-vitro cultivation in macrophages

\begin{tabular}{|c|c|c|c|c|c|c|c|}
\hline \multirow{2}{*}{$\begin{array}{c}\text { Time in macrophage } \\
\text { culture }\end{array}$} & \multicolumn{5}{|c|}{$\begin{array}{l}\text { Number of mouse foot pads } \\
\text { infected/number inoculated } \\
\text { with } M \text {. leprae at a concentration } \\
\text { (cells/inoculum) of }\end{array}$} & \multirow{2}{*}{$\begin{array}{l}\text { Most probable } \\
\text { number viable } \\
\text { organisms } / 10^{4} \\
\text { M. leprae* }\end{array}$} & \multirow[t]{2}{*}{$\begin{array}{l}95 \% \text { Confidence } \\
\text { limits }\end{array}$} \\
\hline & $10^{4}$ & $10^{3}$ & $10^{2}$ & $10^{1}$ & $10^{0}$ & & \\
\hline $\begin{array}{l}\text { Experiment } 1 \\
0 \\
36 \text { hours } \\
90 \text { days }\end{array}$ & $\begin{array}{l}5 / 8 \\
4 / 8 \\
0 / 6\end{array}$ & $\begin{array}{l}3 / 8 \\
1 / 4 \\
0 / 8\end{array}$ & $\begin{array}{l}0 / 7 \\
0 / 8 \\
0 / 8\end{array}$ & $\begin{array}{l}0 / 8 \\
0 / 8 \\
0 / 8\end{array}$ & $\begin{array}{l}0 / 7 \\
0 / 6 \\
0 / 7\end{array}$ & $\begin{array}{c}1 \cdot 41 \\
0 \cdot 81 \\
0\end{array}$ & $\begin{array}{l}0.64-3 \cdot 08 \\
0.32-2.02\end{array}$ \\
\hline $\begin{array}{l}\text { Experiment } 2 \\
0 \\
18 \text { hours } \\
19 \text { days } \\
76 \text { days }\end{array}$ & $\begin{array}{l}7 / 8 \\
4 / 6 \\
2 / 6 \\
0 / 5\end{array}$ & $\begin{array}{l}2 / 6 \\
4 / 8 \\
0 / 8 \\
0 / 8\end{array}$ & $\begin{array}{l}1 / 6 \\
0 / 8 \\
0 / 7 \\
0 / 6\end{array}$ & $\begin{array}{l}0 / 6 \\
0 / 6 \\
0 / 8 \\
0 / 8\end{array}$ & $\begin{array}{l}0 / 6 \\
0 / 8 \\
0 / 7 \\
0 / 8\end{array}$ & $\begin{array}{c}2 \cdot 76 \\
1.97 \\
0 \cdot 34 \\
0\end{array}$ & $\begin{array}{l}1 \cdot 22-6.26 \\
0.84-4.58 \\
0.08-1.36\end{array}$ \\
\hline
\end{tabular}

* Assessed by proportional bacterial test (see text). 
TABLE III

Effect of hydrogen peroxide on the viability of catalase-positive and catalase-negative strains of $M$. tuberculosis

\begin{tabular}{|c|c|c|c|c|c|}
\hline \multirow{3}{*}{$\begin{array}{l}\text { Strain of } \\
M \text {. tuberculosis }\end{array}$} & \multicolumn{5}{|c|}{ Viable bacteria $(\mathrm{cfu}) / \mathrm{ml}$ of culture } \\
\hline & \multirow{2}{*}{$\begin{array}{l}\text { Initial } \\
\text { count }\end{array}$} & \multicolumn{3}{|c|}{ After exposure to $\mathrm{H}_{2} \mathrm{O}_{2} 0.08 \%$ for } & \multirow{2}{*}{$\begin{array}{l}\text { Untreated culture } \\
\text { after } 4.5 \mathrm{~h}\end{array}$} \\
\hline & & $45 \mathrm{~min}$ & $90 \mathrm{~min}$ & $4 \cdot 5 \mathrm{~h}$ & \\
\hline $\begin{array}{l}\text { Catalase positive } \\
20360\end{array}$ & $2.6 \times 10^{6}$ & $2 \cdot 3 \times 10^{6}$ & $1.5 \times 10^{6}$ & $5 \cdot 0 \times 10^{5}$ & $2.9 \times 10^{6}$ \\
\hline $\begin{array}{l}\text { Catalase positive } \\
20403\end{array}$ & $1 \cdot 2 \times 10^{7}$ & $1.0 \times 10^{7}$ & $5.5 \times 10^{6}$ & $4.0 \times 10^{6}$ & $9.5 \times 10^{6}$ \\
\hline $\begin{array}{l}\text { Catalase negative } \\
21718\end{array}$ & $2.9 \times 10^{6}$ & 0 & 0 & 0 & $1.6 \times 10^{6}$ \\
\hline $\begin{array}{l}\text { Catalase negative } \\
21618\end{array}$ & $1 \cdot 2 \times 10^{6}$ & $4 \cdot 2 \times 10^{2}$ & 0 & 0 & $1 \cdot 2 \times 10^{6}$ \\
\hline
\end{tabular}

TABLE IV

Effect of hydrogen peroxide on the viability of Staph. aureus and Str. pyogenes

\begin{tabular}{|c|c|c|c|c|}
\hline \multirow{2}{*}{$\begin{array}{c}\text { Time of exposure } \\
\text { to } \mathrm{H}_{2} \mathrm{O}_{2} 0 \cdot 08 \% \\
\text { or } \mathrm{PBS}(\mathrm{min})\end{array}$} & \multicolumn{2}{|c|}{$\begin{array}{l}\text { Viable staphylococci } \\
(\mathrm{cfu} / \mathrm{ml}) \\
\text { after exposure to }\end{array}$} & \multicolumn{2}{|c|}{$\begin{array}{l}\text { Viable streptococci } \\
(\mathrm{cfu} / \mathrm{ml}) \\
\text { after exposure to }\end{array}$} \\
\hline & PBS & $\mathrm{H}_{2} \mathrm{O}_{2}$ & PBS & $\mathrm{H}_{2} \mathrm{O}_{2}$ \\
\hline \\
\hline 30 & $1.3 \times 10^{7}$ & $1.2 \times 10^{7}$ & $4.8 \times 10^{6}$ & $5.6 \times 10^{6}$ \\
\hline 60 & $1.8 \times 10^{7}$ & $1.1 \times 10^{7}$ & $5 \cdot 2 \times 10^{6}$ & $1.2 \times 10^{6}$ \\
\hline 90 & $1.2 \times 10^{7}$ & $0.9 \times 10^{7}$ & $4.8 \times 10^{6}$ & $0.9 \times 10^{5}$ \\
\hline 120 & $1 \cdot 1 \times 10^{7}$ & $0.7 \times 10^{7}$ & $3.6 \times 10^{6}$ & 0 \\
\hline \multicolumn{5}{|l|}{ Experiment 2} \\
\hline $\begin{array}{r}0 \\
30\end{array}$ & $1.9 \times 10^{6}$ & & $2.8 \times 10^{6}$ & \\
\hline $\begin{array}{l}30 \\
60\end{array}$ & $\begin{array}{l}7.2 \times 10^{3} \\
1.0 \times 10^{6}\end{array}$ & $\begin{array}{l}5.7 \times 10^{3} \\
6.6 \times 10^{5}\end{array}$ & $\begin{array}{l}2.2 \times 10^{6} \\
2.2 \times 10^{6}\end{array}$ & $\begin{array}{l}1.6 \times 10^{6} \\
2.0 \times 10^{4}\end{array}$ \\
\hline 90 & $5.2 \times 10^{5}$ & $3.5 \times 10^{5}$ & $1.5 \times 10^{6}$ & 0 \\
\hline 120 & $5.9 \times 10^{5}$ & $0.9 \times 10^{5}$ & $1.3 \times 10^{6}$ & 0 \\
\hline 420 & $3.2 \times 10^{5}$ & $4.4 \times 10^{4}$ & $6.6 \times 10^{5}$ & 0 \\
\hline
\end{tabular}

TABLE V

Effect of hydrogen peroxide on the viability of $M$. leprae

\begin{tabular}{|c|c|c|c|c|c|c|c|}
\hline \multirow{2}{*}{$\begin{array}{l}\text { Time of } \\
\text { pre-exposure } \\
\text { to } \mathrm{H}_{2} \mathrm{O}_{2}\end{array}$} & \multicolumn{5}{|c|}{$\begin{array}{c}\text { Number of } \\
\text { foot pads infected/number inoculated } \\
\text { with } M \text {. leprae at concentrations (cell/inoculum) of }\end{array}$} & \multirow{2}{*}{$\begin{array}{c}\text { Most probable } \\
\text { number viable } \\
\text { organisms } / 10^{4} \\
\text { M. leprae* }\end{array}$} & \multirow{2}{*}{$\begin{array}{c}95 \% \text { Confidence } \\
\text { limits }\end{array}$} \\
\hline & $10^{4}$ & $10^{3}$ & $10^{2}$ & $10^{1}$ & $10^{0}$ & & \\
\hline $\begin{array}{l}0 \\
30 \mathrm{~min} \\
90 \mathrm{~min} \\
24 \mathrm{~h} \\
24 \mathrm{~h} \\
\text { untreated }\end{array}$ & $\begin{array}{l}8 / 8 \\
3 / 8 \\
1 / 8 \\
0 / 8 \\
8 / 8\end{array}$ & $\begin{array}{l}7 / 8 \\
1 / 8 \\
0 / 8 \\
0 / 8 \\
6 / 8\end{array}$ & $\begin{array}{l}1 / 8 \\
0 / 8 \\
0 / 8 \\
0 / 8 \\
2 / 8\end{array}$ & $\begin{array}{l}0 / 8 \\
0 / 8 \\
0 / 8 \\
0 / 8 \\
0 / 8\end{array}$ & $\begin{array}{l}0 / 8 \\
0 / 8 \\
0 / 8 \\
0 / 8 \\
0 / 8\end{array}$ & $\begin{array}{c}18 \cdot 55 \\
0 \cdot 55 \\
0 \cdot 12 \\
0 \\
15 \cdot 93\end{array}$ & $\begin{array}{l}8 \cdot 66-39 \cdot 75 \\
0 \cdot 20-1 \cdot 52 \\
0 \cdot 02-0 \cdot 84 \\
7 \cdot 38-34 \cdot 38\end{array}$ \\
\hline
\end{tabular}

*Assessed by proportional bactericidal test (see text). 
seen that a 30-min exposure to $\mathrm{H}_{2} \mathrm{O}_{2}$ resulted in a dramatic reduction in viability $(98 \%)$. After $90 \mathrm{~min},>99 \%$ of the bacilli which were initially viable had been killed, and by 24 $\mathrm{h}$ there were no detectable viable bacilli. That this rapid reduction in viability was attributable to the bactericidal activity of $\mathrm{H}_{2} \mathrm{O}_{2}$ was demonstrated by the fact that there was no significant reduction in viability during $24 \mathrm{~h}$ when $\mathrm{H}_{2} \mathrm{O}_{2}$ was omitted from the suspension medium.

\section{DisCusSION}

Although $M$. leprae is an intracellular parasite found commonly in the macrophages of susceptible hosts-man (Drutz, Chen and Lu, 1972), nude mice and nude rats (Colston and Hilson, 1976; Dawson, Colston and Fieldsteel, 1983) and armadillos (Kirchheimer and Storrs, 1971)-we have failed to demonstrate its growth in these cells in vitro (Sharp and Banerjee, 1984). One possible explanation for this is that $M$. leprae is highly susceptible to the killing mechanisms of macrophages maintained in vitro but is able to evade these mechanisms in vivo.

In this investigation, we have examined the fate of $M$. leprae cultured in macrophages from nude mice. Experiments designed to compare the clearance of live and killed organisms by macrophages have shown that there is no difference in the rates of bacillary clearance (table I). However, estimates of viability by the proportional bactericidal test (table I), have demonstrated that $M$. leprae is killed within these cells. These findings confirm that mycobacteria are degraded only with difficulty by the macrophage and that dead organisms can retain their acid-fastness for considerable lengths of time. It would appear from these results that $M$. leprae is unable to survive in nude mouse macrophages, and that significant bacterial killing occurs within $24-48 \mathrm{~h}$. It would have been of interest to examine the fate of a $M$. leprae suspension with a higher initial viability during in-vitro cultivation, in view of the tentative correlation that has been observed between the morphological index of a $M$. leprae suspension and its behaviour in macrophage cultures (Sharp and Banerjee, 1984). However, no correlation was observed in that study between the growth of $M$. leprae in mouse footpads, and 'growth' in macrophages in vitro, which would suggest that even with a high viability $M$. leprae does not survive in these conditions.

Our results do not answer the question of whether $M$. leprae in nude mouse macrophages in vitro is undergoing a natural death or whether a positive killing mechanism operates within the macrophage. However, it seems unlikely that the significant loss of viability seen here within $24-48 \mathrm{~h}$ would result from natural death, particularly as no such loss of viability was seen in the control suspension for the $\mathrm{H}_{2} \mathrm{O}_{2}$ experiment (table IV). This suggests that bacilli were killed by macrophage-mediated mechanisms.

Although the difficulty in distinguishing between host-derived and $M$. leprae-derived enzyme is emphasised, studies of $M$. leprae from armadillos suggest that this organism is catalase negative (Wheeler and Gregory, 1980; Katoch et al., 1982). If this is so, it may be susceptible to killing by $\mathrm{H}_{2} \mathrm{O}_{2}$, one of the important oxygen-dependent bactericidal metabolites of the macrophage. Our results have shown that $M$. leprae rapidly loses viability in the presence of $\mathrm{H}_{2} \mathrm{O}_{2}$. We have also shown that catalase-negative strains of $M$. tuberculosis are killed in similar circumstances whereas catalasepositive strains are capable of survival, thus confirming the more extensive work of 
Jackett et al. (1978). The implication is that $M$. leprae is, at least to some extent, depleted of catalase activity and is therefore likely to be sensitive to macrophage killing mechanisms.

It has been shown that peritoneal macrophages from nude mice have increased activity and, when compared to those from normal mice, are able to produce more superoxide and $\mathrm{H}_{2} \mathrm{O}_{2}$ (Sharp and Colston, 1984). Because superoxide dismutase activity has been associated with $M$. leprae (Wheeler and Gregory, 1980), the bactericidal effects of superoxide may be of little importance except indirectly because of its dismutation (especially in the presence of superoxide dismutase) to form $\mathrm{H}_{2} \mathrm{O}_{2}$. $M$. leprae would seem inadequately equipped enzymatically to protect itself from the killing effects of $\mathrm{H}_{2} \mathrm{O}_{2}$, although it may possess protective mechanisms against other bactericidal components of the macrophage. Thus it seems likely that $\mathrm{H}_{2} \mathrm{O}_{2}$, which we have shown to be bactericidal for $M$. leprae and which is produced in comparatively large quantities by nude mouse macrophages (Sharp and Colston, 1984), is the major cause of the loss of viability observed when $M$. leprae is cultured in these host cells. We remain, however, unable to explain why this killing effect is not operative in nude mouse macrophages in vivo. The possibility of an in-vivo suppressor mechanism which prevents macrophages from exerting a bactericidal effect needs to be investigated.

This investigation was supported by the Wellcome Trust and the UNDP/World Bank/WHO Special Programme for Research and Training in Tropical Diseases.

\section{REFERENCES}

Brown C A, Brown I N 1982 Mycobacterium bovis, BCG, modulation of murine antibody responses: influence of dose and degree of aggregation of live or dead organisms. British Journal of Experimental Pathology 63:133-143.

Chang Y T 1964 Long-term cultivation of mouse peritoneal macrophages. Journal of National Cancer Institute 32:19-35.

Chang Y T, Neikirk R L 1965 Mycobacterium lepraemurium and Mycobacterium leprae in cultures of mouse peritoneal macrophages (Preliminary results). International Journal of Leprosy 33:586-603.

Collins C H, Lyne P M 1970 Microbiological methods, 3rd edn. Butterworths, London p 180.

Colston M J, Hilson G R F 1976 Growth of Mycobacterium leprae and M. marinum in congenitally athymic (nude) mice. Nature 262:399-401.

Colston M J, Hilson G R F, Banerjee D K 1978 The 'proportional bactericidal test': a method for assessing bactericidal activity of drugs against Mycobacterium leprae in mice. Leprosy Review 49:7-15.

Dawson P J, Colston M J, Fieldsteel A H 1983 Infection of the congenitally athymic rat with Mycoacterium leprae. International Journal of Leprosy 51:336-346.

Drutz D J, Chen T S N, Lu W H 1972 The continuous bacteremia of lepromatous leprosy. New England Journal of Medicine 287:159-164.

Haidaris C G, Bonventre P F 1982 A role for oxygen-dependent mechanisms in killing of Leishmania donovani tissue forms by activated macrophages. Journal of Immunology 129:850-855.

Halvorson H O, Ziegler N R 1933 Application of statistics to problems in bacteriology. 1. A means of determining bacterial population by the dilution method. Journal of Bacteriology 25:101-121.

Hilson G R F, Banerjee D K 1974 The proportional bactericidal test: a method for testing in vivo bactericidal action of a persistent drug. IRCS: Medical Science 2:1037.

Holmes I B, Hilson G R F 1972 The effect of rifampicin and dapsone on experimental Mycobacterium leprae infections: minimum inhibitory concentrations and bactericidal action. Journal of Medical Microbiology 5:251-261. 
Jackett P S, Aber V R, Lowrie D B 1978 Virulence and resistance to superoxide, low $p \mathrm{H}$ and hydrogen peroxide among strains of Mycobacterium tuberculosis. Journal of General Microbiology 104:37-45.

Katoch V M, Wayne L G, Diaz G A 1982 Serological approaches for the characterization of catalase in tissue-derived mycobacteria. Annales de Microbiologie (Institut Pasteur) 133B:407-414.

Kirchheimer W F, Storrs E E 1971 Attempts to establish the armadillo (Dasypus novemcinctus Linn) as a model for the study of leprosy. 1. Report of lepromatoid leprosy in an experimentally infected armadillo. International Journal of Leprosy 39:693-702.

Samuel D R, Godal T, Myrvang B, Song Y K 1973 Behaviour of Mycobacterium leprae in human macrophages in vitro. Infection and Immunity 8:446-449.

Sharp A K, Colston M J 1984 The regulation of macrophage activity in congenitally athymic mice. European Journal of Immunology 14:102-105.

Sharp A K, Banerjee D K 1984 Attempts at cultivation of Mycobacterium leprae in macrophages from susceptible animal hosts. International Journal of Leprosy 52:189-197.

Walker L, Lowrie D B 1981 Killing of Mycobacterium microti by immunologically activated macrophages. Nature 293:69-70.

Wheeler P R, Gregory D 1980 Superoxide dismutase, peroxidatic activity and catalase in Mycobacterium leprae purified from armadillo liver. Journal of General Microbiology 121:457-464.

Yamagami A, Chang Y T 1977 Growth of Mycobacterium lepraemurium in cultures of macrophages obtained from various sources. Infection and Immunity 17:531-534. 